\title{
IJPPR
}

Human Journals

Research Article

December 2019 Vol.:17, Issue:1

(C) All rights are reserved by Richa Ohri et al.

\section{Formulation and Evaluation of Floating Tablets of Ranitidine Hydrochloride with Liquorice as Natural Ulcer Protective Agent}

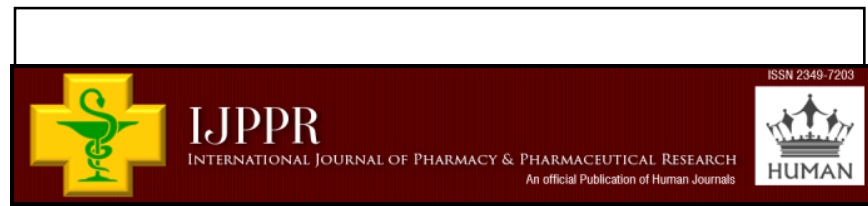

Poonam Sansarwal $^{1}$, Sunaina Sharma ${ }^{1}$, Richa Ohri ${ }^{2 *}$

1. Himalayan Institute of Pharmacy, Kala-amb, Himachal Pradesh, India-173030

2. LBR college of Pharmacy, Panchkula, Haryana, India-134109

Submission: 23 November 2019

Accepted: $\quad 29$ November 2019

Published: $\quad 30$ December 2019
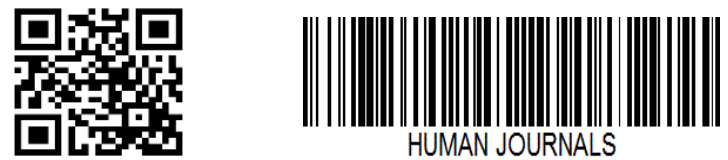

www.ijppr.humanjournals.com
Keywords: Ranitidine $\mathrm{HCl}$, Absorption window, Bioavailability, Floating dosage form

ABSTRACT

The concurrent trend in pharmaceutical evolution accentuates the effectiveness of floating tablets over conventional dosage form. Furthermore, it facilitates site-specificity, controlled release and is irrespective of gastric emptying. The present study was carried out to enhance the bioavailability of Ranitidine $\mathrm{HCl}$, a floating dosage form with controlled release. Ranitidine $\mathrm{HCl}$ has a narrow absorption window in the gastrointestinal tract; therefore its absorption was improved by modifying the dosage form. The action potential of a drug is synergized by combining it with a natural ulcer protective agent that is liquorice. The tablets were prepared by wet granulation method. The batches were formulated using a different ratio of HPMC K15 and Carbopol. It ensures the effectiveness of the formulation variable on drug release and buoyancy property of the delivery system. The prepared formulations show significant results obtained by pharmacopoeial quality control tests. In-vitro dissolution study was also performed to check whether the ratio of polymers was optimum for controlled release or not. The present study suggests that the Ranitidine $\mathrm{HCl}$ and liquorice together are well compatible with each other. However, the effectiveness of the drug combination partially depends upon the ratio of polymers. 


\section{www.ijppr.humanjournals.com}

\section{INTRODUCTION}

Most of the medicaments are administered by oral route due to high patient compliance. However, the ideal drug delivery system needs two basic components. Firstly, the drug should be delivered at a predetermined rate for a prolonged time, for the prevention of fluctuation in plasma concentration. Secondly, the drug should bind solely to its selective receptor. Unfortunately, available systems do not relay such kind of properties. Hence the time demands modification in conventional dosage form for the betterment of therapeutic efficacy and drug safety $[1,2]$.

Manufacturing sustained release or controlled release drug delivery systems can help overcome the above-mentioned drawbacks. For instance, the major risk factor is decreased bioavailability due to the narrow absorption window. So far several new approaches such as bioadhesive, floating, swelling-activated drug delivery systems were made to lengthen the Gastric Retention Time (GRT)[3]. The existing trend in pharmaceutical evolution accentuates the effectiveness of floating tablets over conventional dosage form. On inference, it facilitates site-specificity, controlled release and is irrespective of gastric emptying[4, 5].Floating tablet tending to keep afloat for several hours. The buoyancy of tablets is achieved by gas generating agents that liberates carbon dioxide when came in contact with gastric fluid. Besides this, acidic $\mathrm{pH}$ assists entrapment of released $\mathrm{CO}_{2}$ in hydrocolloid gel that maintains extended floatation over long duration. There may be uncertain emptying of the floating system by settling in the stomach due to initial high density which goes down with time. on this emphasis floating system require an adequate amount of gastric fluid for tablet buoyancy[6].

The present study deals with the development of floating tablets of Ranitidine $\mathrm{HCl}$ in combination with natural ulcer protective agent that is liquorice. Ranitidine $\mathrm{HCl}$ abates acid secretion in the stomach by blocking histamine receptor $\mathrm{H}_{2}$. Liquorice is found to be effective in the treatment of gastric ulcers due to the antiulcer and anti-inflammatory properties of glycyrrhetinic acid[7, 8]. Liquorice elevates prostaglandin concentration in the digestive system that assists mucous secretion. Also, the antipepsin effect of liquorice perpetuates the life span of surface cells in the stomach[9]. 
www.ijppr.humanjournals.com

\section{MATERIALS AND METHODS:}

\section{MATERIALS:}

Ranitidine $\mathrm{HCl}$ (received as a gift sample from ZEE Labs Paonta Sahib, H.P ), Liquorice(extracted received as a gift sample from Konark herbal and health care, Kala Amb, H.P), Citric acid, Sodium bicarbonate, Carbopol, HPMC K15, Talc, Magnesium stearate, Ethanol, Hydrochloric acid, Sodium hydroxide, Potassium hydrogen diphosphate (SD fine chemicals).

\section{METHODS}

\section{Construction of Calibration Curve:}

\section{Preparation of simulated gastric fluid (SGF)[10]}

$2 \mathrm{~g}$ of sodium chloride was dissolved in $500 \mathrm{ml}$ deionized water, followed by adding $7 \mathrm{ml}$ of concentrated $\mathrm{HCl}$ and final volume made up to $1000 \mathrm{ml}$ with water. The $\mathrm{pH}$ of the solution was adjusted to 1.2 with $0.1 \mathrm{~N} \mathrm{HCl}$.

\section{Preparation of sample solutions of Ranitidine $\mathrm{HCl}$}

The primary stock solution was prepared by dissolving $112 \mathrm{mg}$ of pure Ranitidine $\mathrm{HCl}$ equivalent to $100 \mathrm{mg}$ in $100 \mathrm{ml}$ SGF $\mathrm{pH} 1.2$ to get a concentration of $1 \mathrm{mg} / \mathrm{ml}$.

Secondary stock solution $5 \mathrm{ml}$ was pipetted out from the primary stock solution and transferred into $50 \mathrm{ml}$ volumetric flask, the final volume was made up to $50 \mathrm{ml}$ using SGF $\mathrm{pH}$ 1.2

Further sample solution of concentration $20 \mu \mathrm{g} / \mathrm{ml}, 40 \mu \mathrm{g} / \mathrm{ml}, 60 \mu \mathrm{g} / \mathrm{ml}, 80 \mu \mathrm{g} / \mathrm{ml}, 100 \mu \mathrm{g} / \mathrm{ml}$ were prepared from secondary stock solution. The absorbance was measured at $314 \mathrm{~nm}$ by UV spectrophotometer (Labindia Analytical) using SGF pH 1.2 as a blank solution.

The calibration curve was plotted against concentration (x-axis) and absorbance (y-axis).

\section{Compatibility studies:}

Were performed by FT-IR of drug liquorice and polymers, and then interpretation was done to check compatibility. 


\section{www.ijppr.humanjournals.com}

\section{Formulation of tablet by wet granulation method:}

Accurate quantity of Ranitidine $\mathrm{HCl}$, liquorice were weighed and separately passed through a sieve of mesh size 40\#, then mixed well. After those polymers i.e. HPMC K15 and Carbopol were mixed in required quantity to the mixture of drugs. Then added the sodium bicarbonate and citric acid in the mixture and mix well, these act as effervescent agents that maintain the floating properties of tablets. Wet mass of mixture was made with the help of $95 \%$ ethanol (granulating agent) and wet screening was done through a sieve with mesh aperture 10\#. Drying of granules was done in a hot air oven at $40^{\circ} \mathrm{C}$ using a tray drying technique. Dry granules are sifted through a sieve with mesh aperture 40\#, and about $15 \%$ of the fine is allowed to remain in the granules. Finally, the dried granules are blended along with magnesium stearate and talc in an octagonal blender. Then the blend was compressed using a caimach compression machine.

Table No. 1: Composition of one tablet for different batches

\begin{tabular}{|l|c|c|c|c|c|}
\hline \multicolumn{7}{|c|}{ Batch code } \\
\hline $\begin{array}{c}\text { Composition } \\
\text { (Qty in mg) }\end{array}$ & $\mathbf{F}_{\mathbf{1}}$ & $\mathbf{F}_{\mathbf{2}}$ & $\mathbf{F}_{\mathbf{3}}$ & $\mathbf{F}_{\mathbf{4}}$ & $\mathbf{F}_{\mathbf{5}}$ \\
\hline Ranitidine HCl & 168 & 168 & 168 & 168 & 168 \\
\hline Liquorice & - & 50 & 50 & 50 & 50 \\
\hline HPMC K15 & 25 & 50 & 50 & 50 & 10 \\
\hline Carbopol & 50 & 25 & 50 & 10 & 50 \\
\hline Citric acid & 10 & 10 & 10 & 10 & 10 \\
\hline Sodium bicarbonate & 50 & 60 & 70 & 80 & 90 \\
\hline Talc & 5 & 5 & 5 & 5 & 5 \\
\hline Magnesium stearate & 7 & 7 & 7 & 7 & 7 \\
\hline
\end{tabular}

\section{Pre-compression evaluation:[11, 12]}

1. Bulk density and tapped density

2. Angle of repose

3. Compressibility index

4. Hausner's ratio 
Bulk density: $20 \mathrm{gm}$ of granules were weighed and poured in measuring cylinder, bulk volume was measured. Bulk density was calculated using the formula:

\section{Bulk density $=($ mass of granules/bulk volume $) \times 100$}

Tapped density: The measuring cylinder was tapped to get constant volume, followed by calculating tapped density using the expression:

\section{Tapped density $=($ mass of granules/tapped volume of granules $) \times 100$}

The angle of repose $(\theta)$ : a heap of the blend was formed using a funnel, followed by measuring height and radius of it.

$$
\begin{gathered}
\tan \theta=h / r \\
\theta=\tan ^{-1}(h / r)
\end{gathered}
$$

Where

$\theta=$ angle of repose

$\mathrm{h}=$ height of heap of blend

$\mathrm{r}=$ radius of a heap of blend

Compressibility index \& Hausner's ratio: were determined by substituting the value of bulk density and tapped density in the formula:

Compressibility index $=($ Tapped density-bulk density $/$ Tapped density $) \times 100$

\section{Hausner's ratio $=$ Tapped density $/$ bulk density}

\section{Evaluation of tablets:}

The prepared tablets were evaluated based on following parameters: 


\section{Physicochemical evaluation of floating tablets [13-15]}

\section{Weight variation}

Twenty tablets were taken from the lot and their weight was measured followed by average weight. Then deviations from the average weight were calculated and compared with an IP 2014 limit of weight variation.

\section{Diameter and thickness:}

They were measured with the help of Vernier calliper.

\section{Friability:}

Roche friabilator was used to determine the friability. 20 tablets were selected and weighed $\left(\mathrm{W}_{\text {initial }}\right)$ and transferred to the friabilator. The friabilator was rotated at $25 \mathrm{rpm}$ for 4 minutes. Then final weights of tablets were observed i.e. $\mathrm{W}_{\text {final }}$. Percentage of friability was calculated using an expression:

$$
\% \text { Friability }=\left(W_{\text {initial }}-W_{\text {final }} / W_{\text {initial }}\right) \times 100
$$

\section{Hardness:}

Monsanto hardness tester was used to determine the hardness of tablets $\left(\mathrm{Kg} / \mathrm{cm}^{2}\right)$.

\section{Swelling index:}

It was determined by keeping tablets in simulated gastric fluid. The swollen weight of tablets was observed at different time intervals. Then the swelling index was calculated using the formula:

\section{Swelling index $=($ wet weight-dry weight/dry weight $) X 100$}

\section{In-vitro buoyancy study:}

Floating lag time and total floating time was evaluated for all batches of Ranitidine $\mathrm{HCl}$. To determine floating lag time a tablet was selected randomly from each batch and kept in 100 $\mathrm{ml}$ beaker containing simulated gastric fluid $(\mathrm{pH} 1.2)$. Floating lag time was the time taken by each tablet to rise and float on the surface of a fluid. 
The dissolution apparatus USP type II (paddle) method was used to determine the total floating time of the tablet. One tablet from all batches was kept in $900 \mathrm{ml}$ simulated gastric fluid ( $\mathrm{pH} \mathrm{1.2)} \mathrm{with} 100 \mathrm{rpm}$ at $37^{\circ} \mathrm{C}$ for 12 hours. The time during which tablets remains constantly on the surface of the medium was recorded as total floating time.[16]

\section{In-vitro drug release study:}

USP type II dissolution test apparatus was used to characterize the in-vitro release profile of formulated floating tablets. The dissolution vessel of the apparatus was filled with $900 \mathrm{ml}$ of simulated gastric fluid. The temperature was set to $37^{\circ} \mathrm{C}$ and speed to $100 \mathrm{rpm} .5 \mathrm{ml}$ of sample was withdrawn at a predetermined time interval of every one hour for up to 12 hours and the same was replaced with fresh medium immediately. The dilution of the sample was prepared by diluting $2 \mathrm{ml}$ with $50 \mathrm{ml}$ of medium in a volumetric flask and filtered through a $0.45 \mu$ membrane filter. Further to determine drug content samples were analyzed against simulated gastric fluid as a blank using HPLC at $320 \mathrm{~nm}$. (1:1) the mixture of methanol-0.01 $\mathrm{M} \mathrm{Na}_{2} \mathrm{HPO}_{4}(\mathrm{pH} 7.0$ ) was used as the mobile phase at flow rate $1 \mathrm{ml} / \mathrm{min}$.[17]

\section{RESULTS AND DISCUSSION}

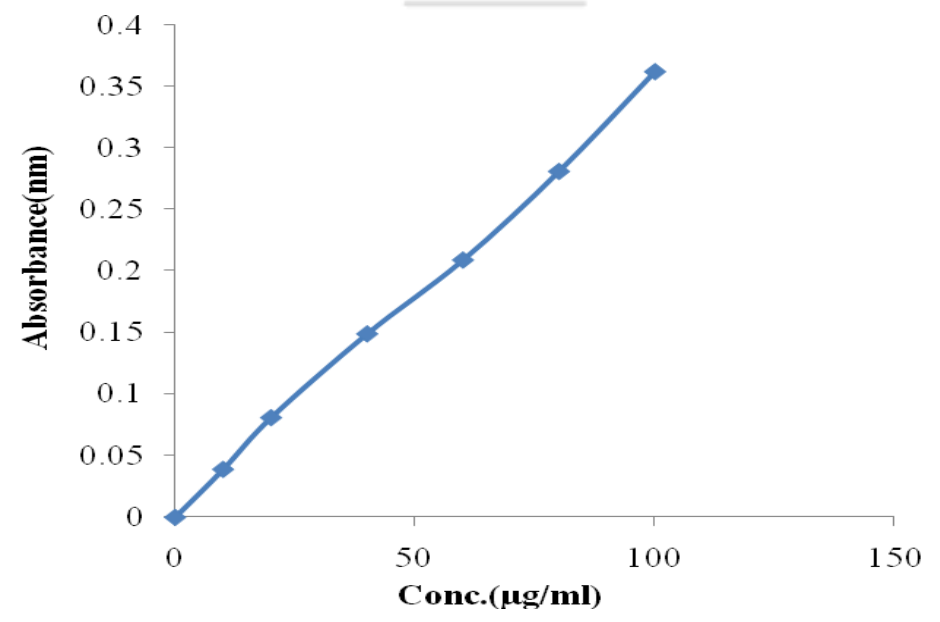

Figure No. 1: Calibration curve for Ranitidine $\mathrm{HCl}$ 
www.ijppr.humanjournals.com

\section{Drug-Excipient compatibility studies:}

Study was performed with the help of FTIR Method.

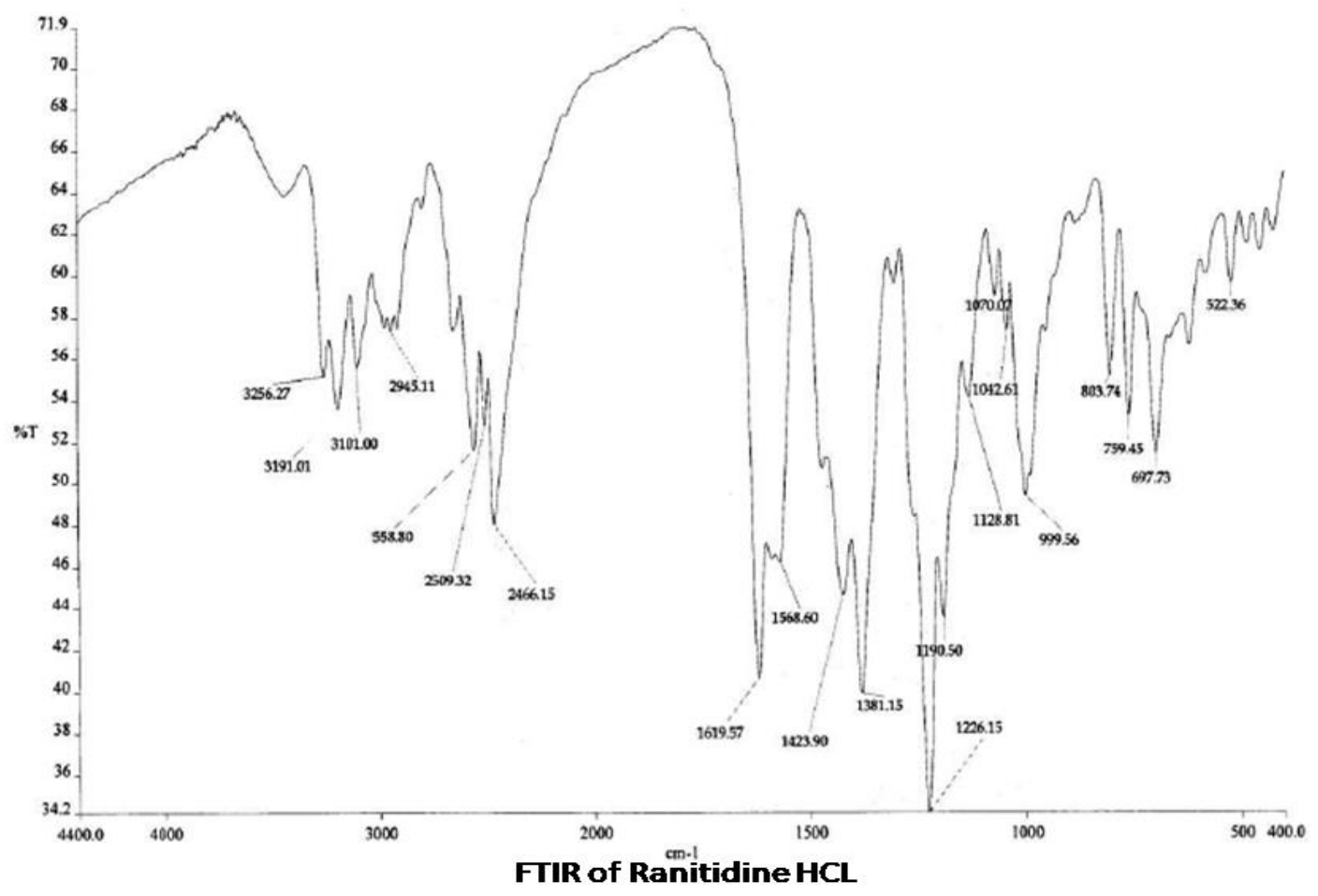

Figure No. 2: FTIR graph of Ranitidine HCl

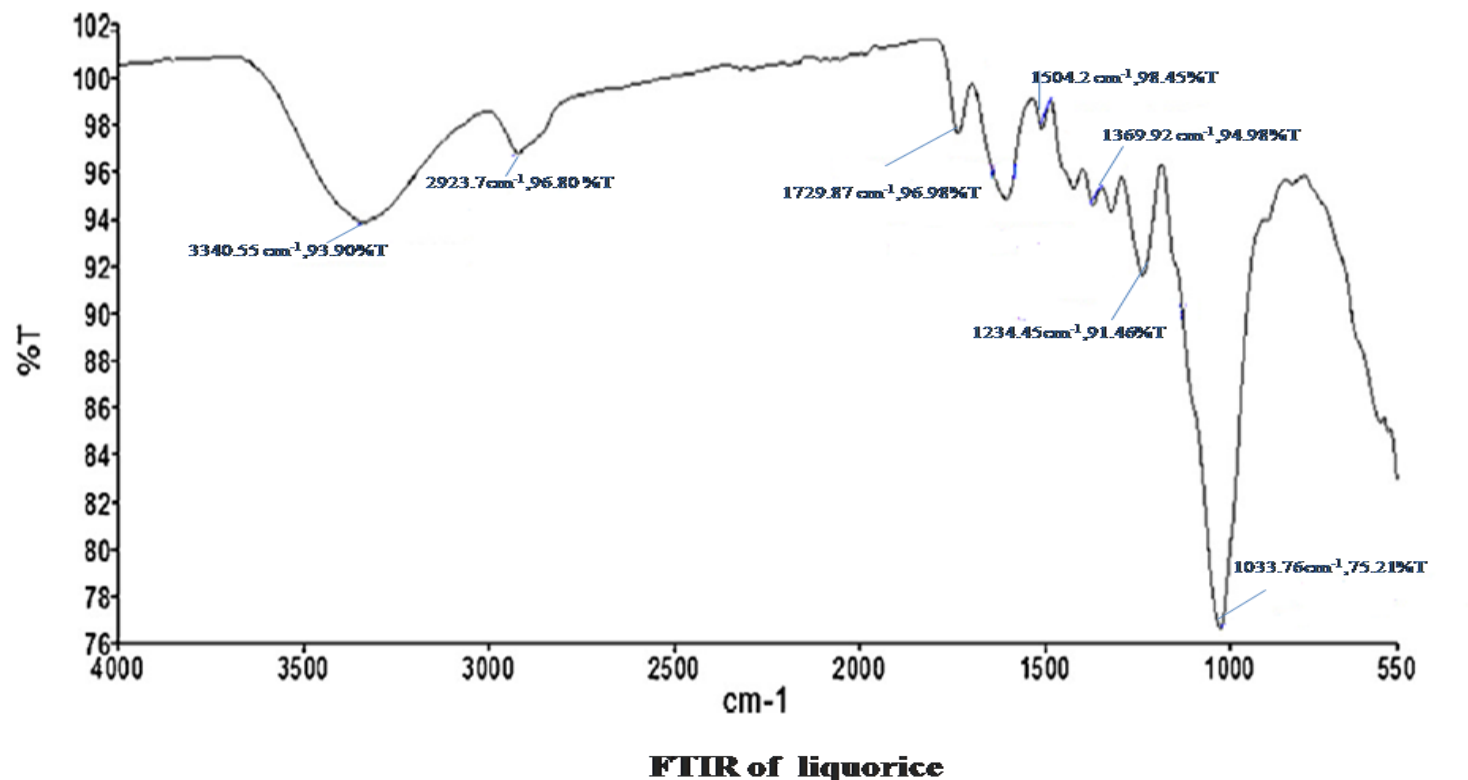

Figure No. 3: FTIR graph of Liquorice 


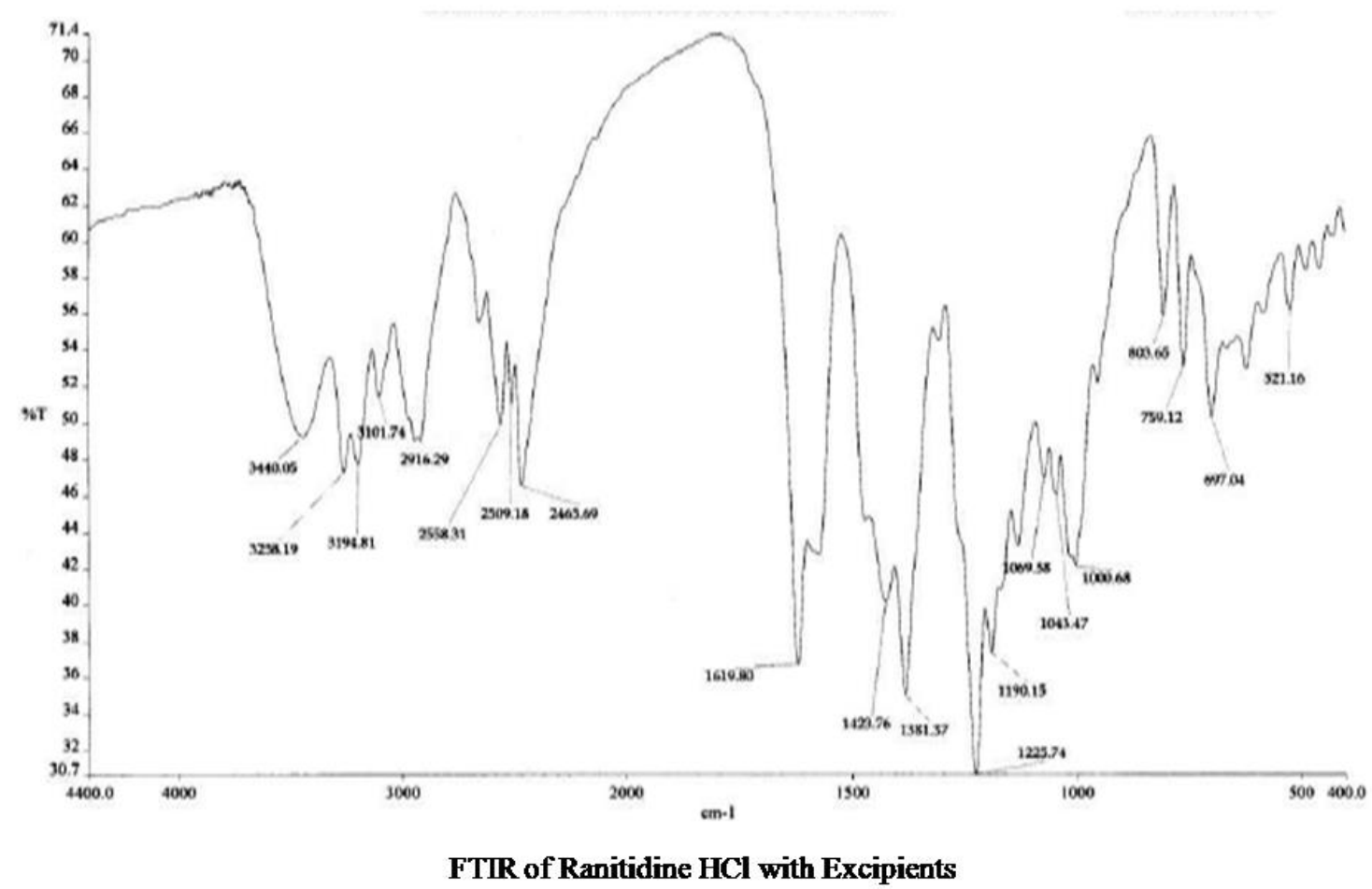

Figure No. 4: FTIR of a mixture of Ranitidine HCl, liquorice, HPMC K15, and Carbopol

Drug- Excipient interaction was studied with FTIR to check whether there is any reaction between drugs and polymers. FTIR of standard drug i.e. Ranitidine $\mathrm{HCl}$ is shown in figure 2.2. When the drug was mixed with the liquorice and other excipients, no interaction was found as there is no disappearance and change in principle peaks of the Ranitidine HCl FTIR as shown in Figure No. 4.

\section{Precompression evaluation:}

Precompression evaluation was performed to study the flow properties of granules.

Bulk density varies from $0.29 \mathrm{~g} / \mathrm{ml}$ to $0.46 \mathrm{~g} / \mathrm{ml}$.

Tapped density varies from $0.37 \mathrm{~g} / \mathrm{ml}$ to $0.49 \mathrm{~g} / \mathrm{ml}$.

The angle of repose was found in a range of $24^{\circ} 41^{\prime}$ to $31^{\circ} 61^{\prime}$. All granules show good flow properties.

The compressibility index was found in the range of $11 \%$ to $18 \%$. It shows that based on compressibility index table granules show good flow properties. 
www.ijppr.humanjournals.com

Hausner's ratio was found in the range of 1.05 to 1.24 .

\section{Bulk density and tapped density:}

Values obtained for bulk density and tapped density of different formulation are shown in table -2

Table No. 2: Bulk density and tapped density of granules

\begin{tabular}{|c|c|c|}
\hline Batch code & $\begin{array}{c}\text { Bulk density }(\mathrm{g} / \mathrm{ml}) \\
(\text { Mean } \pm \text { SD) }\end{array}$ & $\begin{array}{c}\text { Tapped density }(\mathbf{g} / \mathbf{m l}) \\
(\text { Mean } \pm \text { SD) }\end{array}$ \\
\hline $\mathrm{F}_{1}$ & $0.45 \pm 0.03$ & $0.37 \pm 0.07$ \\
\hline $\mathrm{F}_{2}$ & $0.38 \pm 0.07$ & $0.37 \pm 0.06$ \\
\hline $\mathrm{F}_{3}$ & $0.33 \pm 0.02$ & $0.43 \pm 0.04$ \\
\hline $\mathrm{F}_{4}$ & $0.29 \pm 0.06$ & $0.41 \pm 0.04$ \\
\hline $\mathrm{F}_{5}$ & $0.46 \pm 0.06$ & $0.49 \pm 0.07$ \\
\hline
\end{tabular}

\section{The angle of Repose:}

The angle of repose for different formulations was found in the range of $24^{\circ} 41^{\prime}$ to $31^{\circ} 61^{\prime}$. Thus granules show good flow properties.

Values obtained are shown in the table- 3.

Table No. 3: Angle of repose of granules

\begin{tabular}{|c|c|}
\hline Batch code & Angle of repose \\
\hline $\mathrm{F}_{1}$ & $24^{\circ} 41^{\prime}$ \\
\hline $\mathrm{F}_{2}$ & $27^{\circ} 48^{\prime}$ \\
\hline $\mathrm{F}_{3}$ & $28^{\circ} 54^{\prime}$ \\
\hline $\mathrm{F}_{4}$ & $26^{\circ} 72^{\prime}$ \\
\hline $\mathrm{F}_{5}$ & $31^{\circ} 61^{\prime}$ \\
\hline
\end{tabular}

\section{Compressibility index}

The compressibility index was found in the range of $11 \%$ to $18 \%$.

Values of Compressibility index obtained are shown in table -4 . 
Table No. 4: Compressibility index of granules of different formulations:

\begin{tabular}{|c|c|}
\hline Batch code & $\begin{array}{c}\text { Compressibility index (\%) } \\
\text { (Mean } \pm \text { SD) }\end{array}$ \\
\hline $\mathrm{F}_{1}$ & $16.33 \pm 0.02$ \\
\hline $\mathrm{F}_{2}$ & $11.76 \pm 004$ \\
\hline $\mathrm{F}_{3}$ & $15.56 \pm 0.03$ \\
\hline $\mathrm{F}_{4}$ & $14.87 \pm 0.04$ \\
\hline $\mathrm{F}_{5}$ & $17.89 \pm 0.05$ \\
\hline
\end{tabular}

\section{Hausner's Ratio:}

Hausner's ratio was found in the 1.05 to 1.24 .

Values obtained for Hausner's ratio shown in Table No. 5.

Table No. 5: Hausner's ratio of granules:

\begin{tabular}{|c|c|}
\hline Batch code & $\begin{array}{c}\text { Hausner's ratio } \\
\text { (Mean } \pm \text { SD) }\end{array}$ \\
\hline $\mathrm{F}_{1}$ & $1.19 \pm 0.02$ \\
\hline $\mathrm{F}_{2}$ & $1.22 \pm 0.02$ \\
\hline $\mathrm{F}_{3}$ & $1.17 \pm 0.03$ \\
\hline $\mathrm{F}_{4}$ & $1.09 \pm 0.01$ \\
\hline $\mathrm{F}_{5}$ & $1.15 \pm 0.02$ \\
\hline
\end{tabular}

\section{Evaluation of tablets:[18]}

\section{Physicochemical evaluation of floating tablets}

Average weight of tablets of all formulation as per composition is $340 \mathrm{mg}, 377 \mathrm{mg}, 382 \mathrm{mg}$, $389 \mathrm{mg}, 392 \mathrm{mg}$ of $\mathrm{F}_{1}, \mathrm{~F}_{2}, \mathrm{~F}_{3}, \mathrm{~F}_{4}, \mathrm{~F}_{5}$ respectively. As per IP limits maximum allowed \% weight variation is $\pm 5 \%$, values obtained are shown in table-6. The tablet shows weight variation within a limit. 
www.ijppr.humanjournals.com

1. Weight variation

Table No. 6: Values of weight variation of different formulations

\begin{tabular}{|c|c|c|}
\hline Batch code & $\begin{array}{c}\text { The average } \\
\text { weight of the } \\
\text { tablet }\end{array}$ & $\begin{array}{c}\text { Weight variation (\%) } \\
\text { (Mean) }\end{array}$ \\
\hline $\mathrm{F}_{1}$ & $340 \mathrm{mg}$ & $+2.5 \%$ \\
\hline $\mathrm{F}_{2}$ & $377 \mathrm{mg}$ & $-1.5 \%$ \\
\hline $\mathrm{F}_{3}$ & $382 \mathrm{mg}$ & $+2.7 \%$ \\
\hline $\mathrm{F}_{4}$ & $389 \mathrm{mg}$ & $+1.8 \%$ \\
\hline $\mathrm{F}_{5}$ & $392 \mathrm{mg}$ & $+1.4 \%$ \\
\hline
\end{tabular}

\section{Diameter and Thickness}

Tablets were round in shape and slightly yellow with no visible cracks all tablets were uniform in dimensions. Diameter and thickness was measured with a Vernier calliper, values obtained are shown in table -7 .

Table No. 7: Diameter and thickness of tablets

\begin{tabular}{|c|c|c|}
\hline Batch code & $\begin{array}{c}\text { Diameter }(\mathrm{mm}) \\
(\text { Mean } \pm \text { SD) }\end{array}$ & $\begin{array}{c}\text { Thickness }(\mathrm{mm}) \\
(\text { Mean } \pm \text { SD) }\end{array}$ \\
\hline $\mathrm{F}_{1}$ & $9.6 \pm 0.2$ & $5.8 \pm 0.2$ \\
\hline $\mathrm{F}_{2}$ & $9.1 \pm 0.3$ & $6.0 \pm 0.3$ \\
\hline $\mathrm{F}_{3}$ & $9.6 \pm 0.2$ & $6.2 \pm 0.2$ \\
\hline $\mathrm{F}_{4}$ & $9.2 \pm 0.2$ & $5.9 \pm 0.2$ \\
\hline $\mathrm{F}_{5}$ & $9.3 \pm 0.2$ & $6.0 \pm 0.2$ \\
\hline
\end{tabular}

\section{Friability}

Friability of all formulation was found less than $1 \%$ and respective values of different batches are shown in table -8 . Friability varies from $0.47 \%$ to $0.58 \%$. 
Table No. 8: Friability of tablets

\begin{tabular}{|c|c|}
\hline Batch code & Friability (\%) \\
\hline $\mathrm{F}_{1}$ & 0.50 \\
\hline $\mathrm{F}_{2}$ & 0.48 \\
\hline $\mathrm{F}_{3}$ & 0.47 \\
\hline $\mathrm{F}_{4}$ & 0.52 \\
\hline $\mathrm{F}_{5}$ & 0.58 \\
\hline
\end{tabular}

\section{Hardness}

The hardness of tablets was measured with hardness tester and found in the range from 4.8 $\mathrm{Kg} / \mathrm{cm}^{2}$ to $5.4 \mathrm{Kg} / \mathrm{cm}^{2}$. There was no effect of hardness on the release pattern of the drug. Values obtained of hardness for different batches are shown in Table -9.

Table No. 9: Hardness of tablets for different batches

\begin{tabular}{|c|c|}
\hline Batch code & $\begin{array}{c}\text { Hardness }\left(\mathbf{K g} / \mathbf{c m}^{\mathbf{2}}\right) \\
(\text { Mean } \pm \text { SD) }\end{array}$ \\
\hline $\mathrm{F}_{1}$ & $5.2 \pm 0.2$ \\
\hline $\mathrm{F}_{2}$ & $4.9 \pm 0.3$ \\
\hline $\mathrm{F}_{3}$ & $5.4 \pm 0.2$ \\
\hline $\mathrm{F}_{4}$ & $5.1 \pm 0.2$ \\
\hline $\mathrm{F}_{5}$ & $4.8 \pm 0.4$ \\
\hline
\end{tabular}

Swelling index:

Table No. 10: \% swelling index for different batches

\begin{tabular}{|c|c|c|c|}
\hline \multirow{2}{*}{ Batch code } & \multicolumn{3}{|c|}{ \% swelling index with time in hours } \\
\cline { 2 - 4 } & $\mathbf{3}$ & $\mathbf{6}$ & $\mathbf{1 2}$ \\
\hline $\mathrm{F}_{1}$ & $52.47 \%$ & $90.57 \%$ & $136.45 \%$ \\
\hline $\mathrm{F}_{2}$ & $49.62 \%$ & $92.52 \%$ & $141.46 \%$ \\
\hline $\mathrm{F}_{3}$ & $46.74 \%$ & $91.12 \%$ & $148.24 \%$ \\
\hline $\mathrm{F}_{4}$ & $54.56 \%$ & $94.47 \%$ & $157.25 \%$ \\
\hline $\mathrm{F}_{5}$ & $49.52 \%$ & $90.84 \%$ & $152.58 \%$ \\
\hline
\end{tabular}




\section{www.ijppr.humanjournals.com}

\section{In-vitro buoyancy study}

In-vitro buoyancy study was studied in the form of Floating lag time and Total floating time. Floating lag time varied from 51 seconds to 102 seconds. The buoyancy of tablets is mainly due to sodium bicarbonate and citric acid, as sodium bicarbonate release $\mathrm{CO}_{2}$ that cause tablets to remain buoyant in the fluid. Total Floating time varies from $8 \mathrm{hrs}$ to $12 \mathrm{hrs}$.

$\mathrm{F}_{4}$ shows minimum Floating lag time as it starts to float within 51 seconds and maximum floatation for 12 hours. Floating lag time and Total floating time varies due to change in concentration of sodium bicarbonate and little effect of polymer concentration. The obtained values are shown in Table -11 .

Table No. 11: Values for floating lag time and total floating time of all batches

\begin{tabular}{|c|c|c|}
\hline Batch code & $\begin{array}{c}\text { Floating lag time } \\
\text { (seconds) }\end{array}$ & $\begin{array}{c}\text { Total floating time } \\
\text { (Hours) }\end{array}$ \\
\hline $\mathrm{F}_{1}$ & 97 & 8 \\
\hline $\mathrm{F}_{2}$ & 88 & 11 \\
\hline $\mathrm{F}_{3}$ & 102 & 12 \\
\hline $\mathrm{F}_{4}$ & 51 & 12 \\
\hline $\mathrm{F}_{5}$ & 68 & 9 \\
\hline
\end{tabular}

\section{In-vitro dissolution study:}

In-vitro dissolution study was performed to measure the amount of drug released at different time intervals. It was found that $\mathrm{F}_{4}$ shows maximum drug release in 12 hours with a significant difference from other formulations that is $99.67 \%$. There is a direct effect of polymers ratio on drug release. HPMC K15 and Carbopol was taken in various proportions that is $1: 2,2: 1,1: 1,5: 1,1: 5$ for $\mathrm{F}_{1}, \mathrm{~F}_{2}, \mathrm{~F}_{3}, \mathrm{~F}_{4}, \mathrm{~F}_{5}$ respectively. In-vitro release of all formulations is shown in Table No. 12. Based on results, $F_{4}$ was found to be optimized batch as tablets begin to float within 51 seconds, floats for 12 hours and released the maximum quantity of a drug that is $99.67 \%$. 
www.ijppr.humanjournals.com

Table No. 12: Cumulative Percentage of Ranitidine HCL released at different time intervals

\begin{tabular}{|c|c|c|c|c|c|}
\hline \multicolumn{6}{|c|}{ Batch code } \\
\hline $\begin{array}{l}\text { Time } \\
\text { (hours) }\end{array}$ & $\begin{array}{c}F_{1} \\
(\text { Mean } \pm \text { SD })\end{array}$ & $\begin{array}{c}F_{2} \\
(\text { Mean } \pm S D)\end{array}$ & $\begin{array}{c}\mathrm{F}_{3} \\
(\text { Mean } \pm \mathrm{SD})\end{array}$ & $\begin{array}{c}\mathbf{F}_{4} \\
\text { (Mean } \\
\pm \text { SD) }\end{array}$ & $\begin{array}{c}\text { F5 }_{5} \\
(\text { Mean } \pm \text { SD })\end{array}$ \\
\hline 1 & $19.08 \pm 0.81$ & $22.91 \pm 0.78$ & $18.93 \pm 0.69$ & $26.08 \pm 0.64$ & $20.11 \pm 0.72$ \\
\hline 2 & $22.48 \pm 0.64$ & $25.48 \pm 0.62$ & $21.89 \pm 0.68$ & $36.48 \pm 0.67$ & $28.74 \pm 0.69$ \\
\hline 3 & $25.92 \pm 0.73$ & $31.24 \pm 0.64$ & $24.68 \pm 0.61$ & $45.24 \pm 0.69$ & $35.67 \pm 0.64$ \\
\hline 4 & $31.24 \pm 0.65$ & $35.26 \pm 0.62$ & $30.98 \pm 0.68$ & $50.09 \pm 0.59$ & $42.46 \pm 0.59$ \\
\hline 5 & $38.94 \pm 0.68$ & $43.56 \pm 0.56$ & $36.78 \pm 0.59$ & $57.21 \pm 0.64$ & $49.24 \pm 0.63$ \\
\hline 6 & $48.24 \pm 0.54$ & $47.54 \pm 0.52$ & $42.09 \pm 0.66$ & $62.56 \pm 0.58$ & $57.21 \pm 0.57$ \\
\hline 7 & $53.46 \pm 0.48$ & $54.68 \pm 0.49$ & $48.67 \pm 0.58$ & $68.16 \pm 0.54$ & $61.46 \pm 0.58$ \\
\hline 8 & $62.67 \pm 0.55$ & $62.96 \pm 0.46$ & $58.01 \pm 0.55$ & $71.64 \pm 0.52$ & $65.89 \pm 0.54$ \\
\hline 9 & $65.78 \pm 0.45$ & $68.64 \pm 0.43$ & $60.06 \pm 0.54$ & $79.06 \pm 0.53$ & $72.64 \pm 0.45$ \\
\hline 10 & $71.24 \pm 0.47$ & $73.14 \pm 0.39$ & $67.01 \pm 0.59$ & $84.98 \pm 0.49$ & $79.12 \pm 0.47$ \\
\hline 11 & $79.42 \pm 0.46$ & $82.64 \pm 0.46$ & $74.16 \pm 0.49$ & $90.87 \pm 0.46$ & $81.06 \pm 0.44$ \\
\hline 12 & $84.89 \pm 0.44$ & $88.24 \pm 0.48$ & $79.86 \pm 0.46$ & $99.67 \pm 0.39$ & $87.12 \pm 0.38$ \\
\hline
\end{tabular}

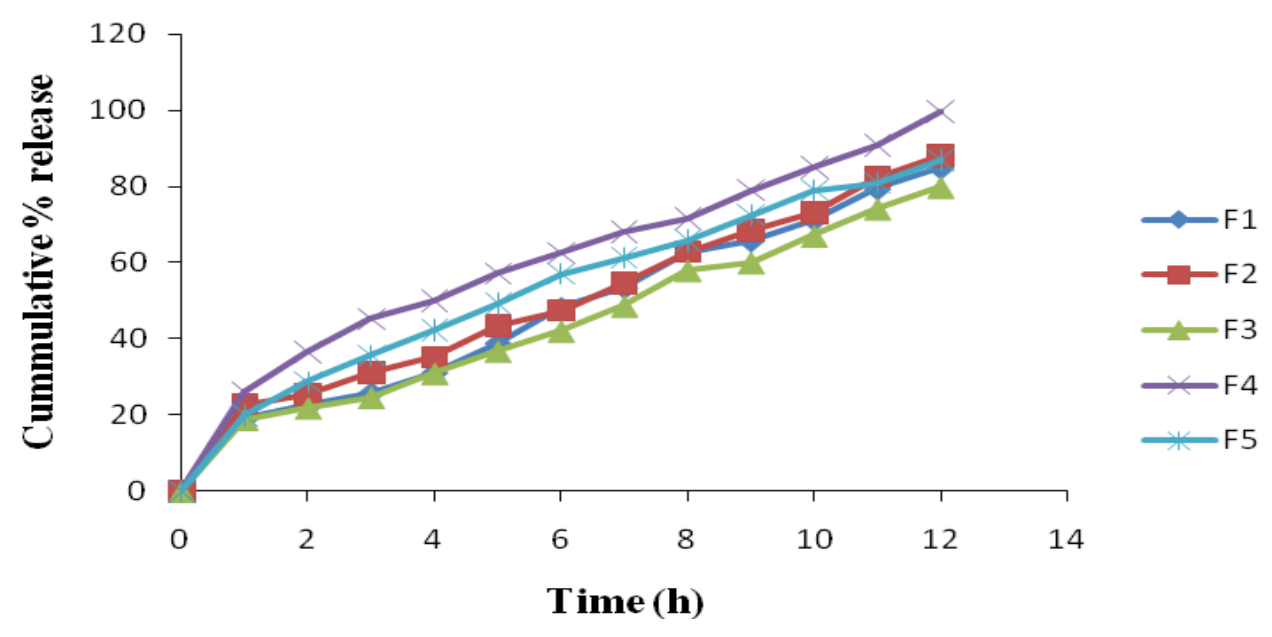

Figure No. 5: Graph showing in-vitro release of different batches 


\section{Kinetic modeling for drug release:}

To find the mechanism of drug release from floating tablets, the dissolution data of optimized formulation i.e. batch $\mathrm{F}_{4}$ were treated with following kinetic models.

- Zero-order release

- First-order release

- Higuchi model

- Korsmeyer Peppas model

\section{Zero-order release:}

A graph was plotted by taking time on $\mathrm{X}$-axis and \% cumulative drug release on $\mathrm{Y}$-axis.

Table No. 13: Data for Zero-order kinetics

\begin{tabular}{|c|c|}
\hline Time (hours) & \% Cumulative drug release \\
\hline 1 & 26.08 \\
\hline 2 & 31.48 \\
\hline 3 & 45.24 \\
\hline 4 & 50.09 \\
\hline 5 & 57.21 \\
\hline 6 & 62.56 \\
\hline 7 & 68.16 \\
\hline 8 & 71.64 \\
\hline 9 & 79.06 \\
\hline 10 & 81.98 \\
\hline 11 & 90.87 \\
\hline 12 & 99.67 \\
\hline
\end{tabular}


www.ijppr.humanjournals.com

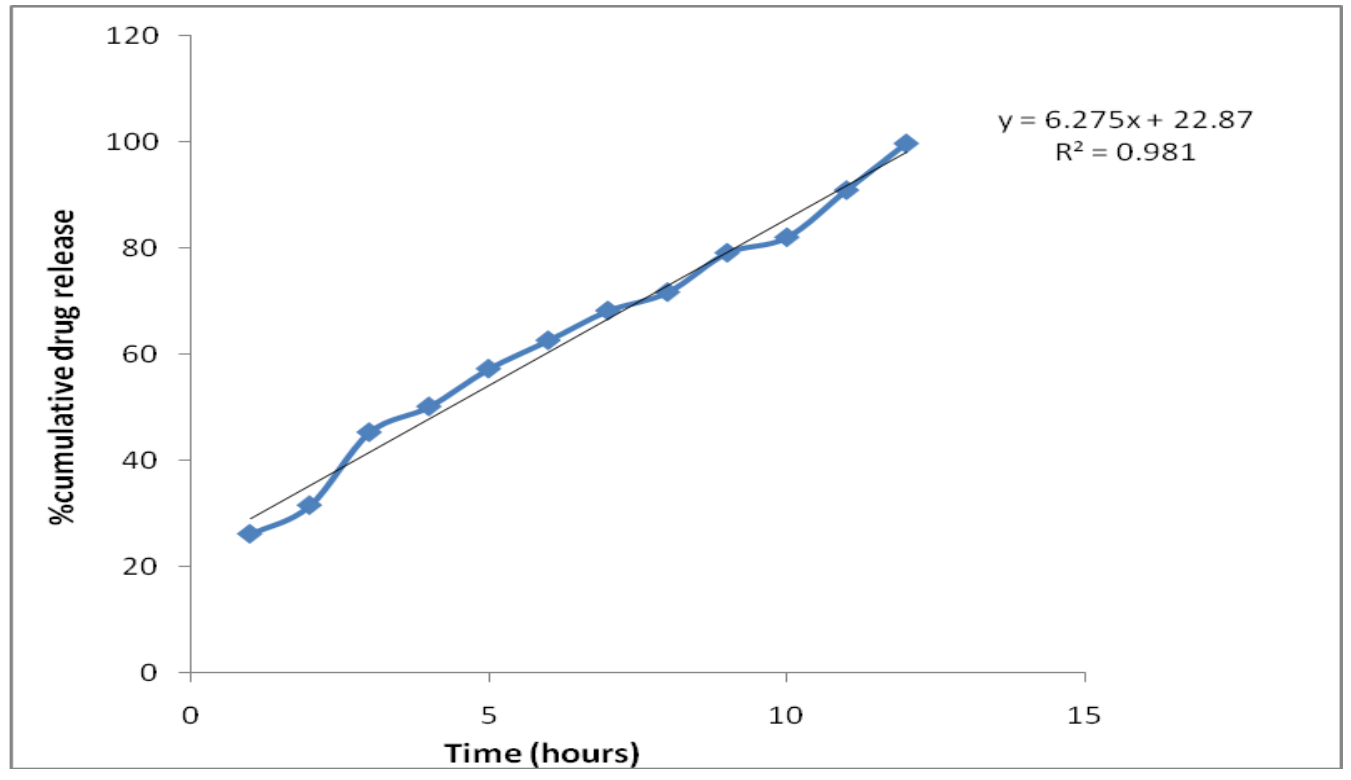

Figure No. 6: Zero-order plot for Dissolution of $\mathbf{F}_{4}$

\section{First order release:}

Graph was plotted by taking time on $\mathrm{X}$-axis and log of \% cumulative drug release on $\mathrm{Y}$-axis.

Table No. 14: Data for First order kinetics

\begin{tabular}{|c|c|}
\hline Time (hours) & $\log$ (\% cumulative release) \\
\hline 1 & 1.416307587 \\
\hline 2 & 1.498034724 \\
\hline 3 & 1.655522596 \\
\hline 4 & 1.699751032 \\
\hline 5 & 1.757471948 \\
\hline 6 & 1.79629674 \\
\hline 7 & 1.833529582 \\
\hline 8 & 1.855155577 \\
\hline 9 & 1.89795681 \\
\hline 10 & 1.913707914 \\
\hline 11 & 1.958420528 \\
\hline 12 & 1.998564458 \\
\hline
\end{tabular}


www.ijppr.humanjournals.com

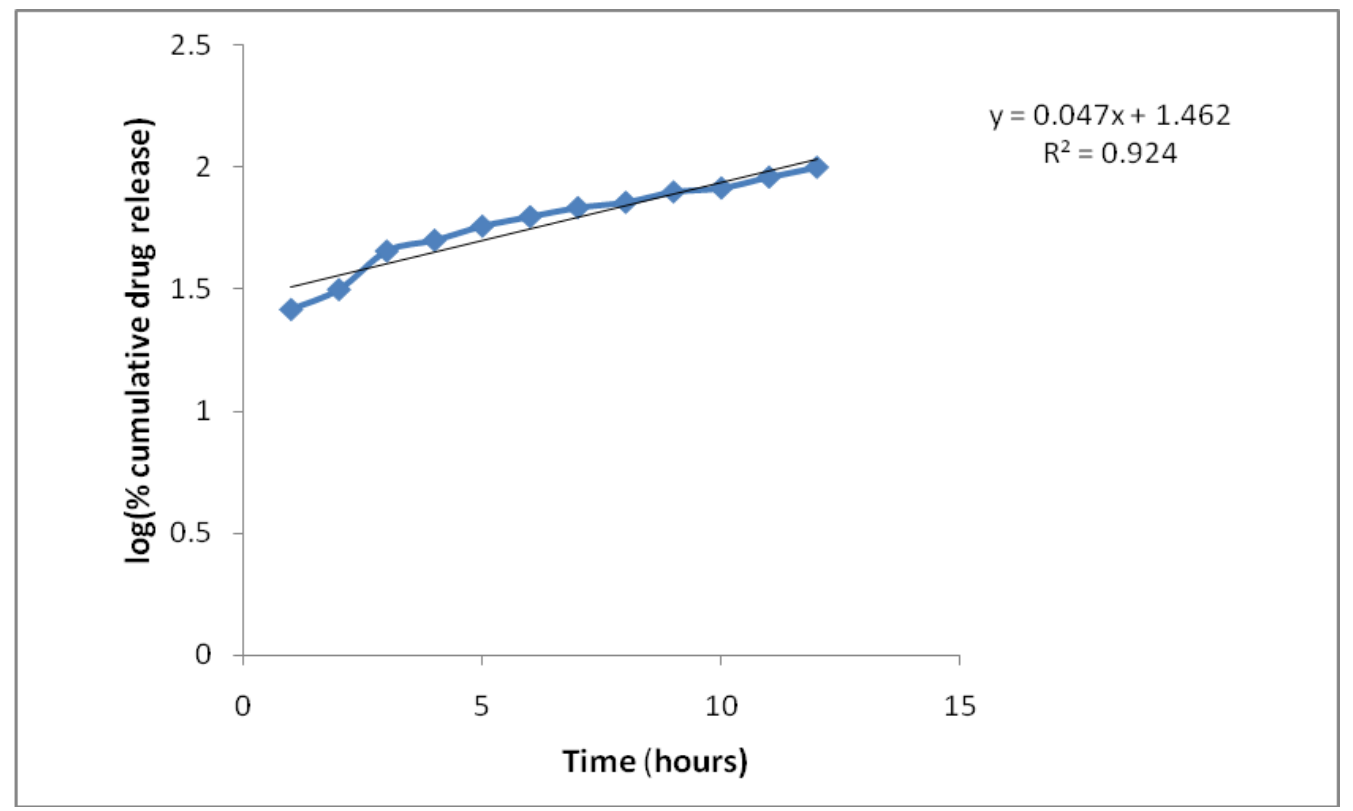

Figure No. 7: First order plot for Dissolution of $\mathbf{F}_{4}$

\section{Higuchi's model:}

Graph was plotted by taking square root of time on $\mathrm{X}$-axis and \% cumulative drug release on Y-axis.

Table No. 15: Data for Higuchi's model

\begin{tabular}{|c|c|}
\hline Square root of time(hours) & \% cumulative drug release \\
\hline 1 & 26.08 \\
\hline 1.414213562 & 31.48 \\
\hline 1.732050808 & 45.24 \\
\hline 2 & 50.09 \\
\hline 2.236067977 & 57.21 \\
\hline 2.449489743 & 62.56 \\
\hline 2.645751311 & 68.16 \\
\hline 2.828427125 & 71.64 \\
\hline 3 & 79.06 \\
\hline 3.16227766 & 81.98 \\
\hline 3.31662479 & 90.87 \\
\hline 3.464101615 & 99.67 \\
\hline
\end{tabular}


www.ijppr.humanjournals.com

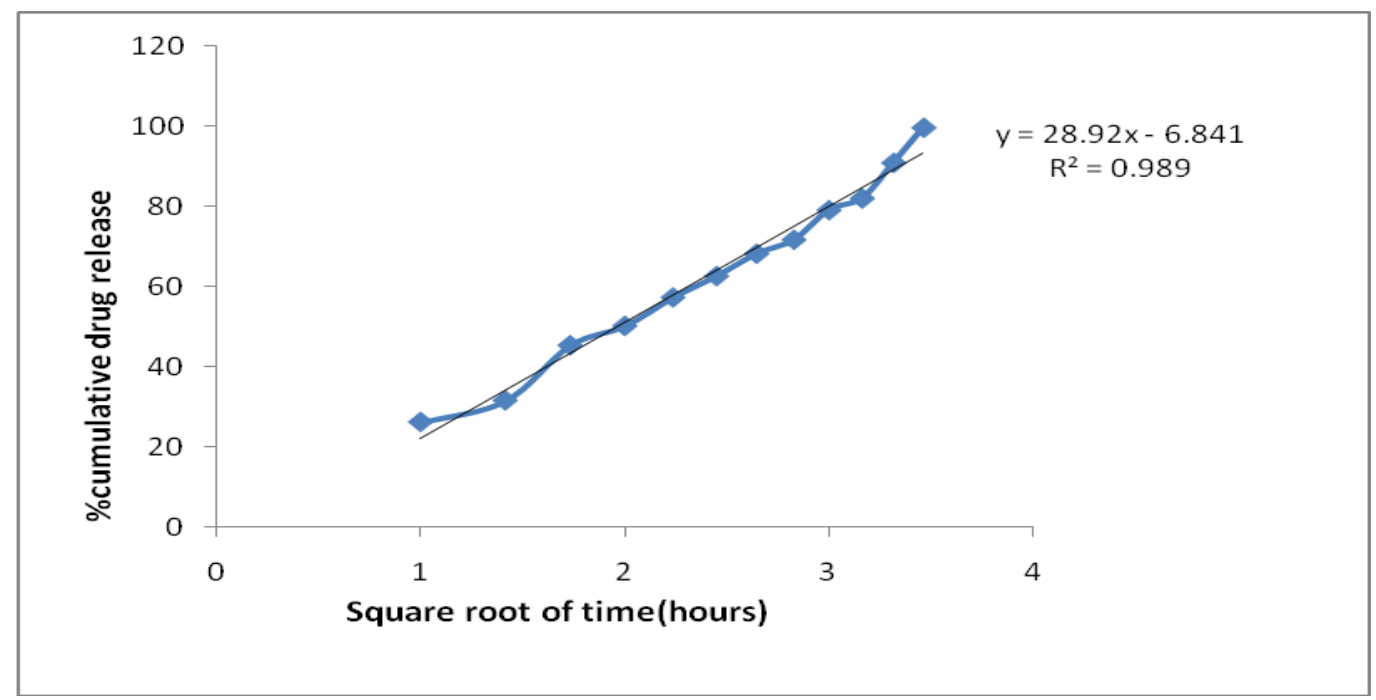

Figure No. 8: Higuchi's plot for Dissolution of $F_{4}$

\section{Korsmeyer Peppas model:}

Graph was plotted by taking log of time on $\mathrm{X}$-axis and log of \% cumulative drug release on Y-axis.

Table No. 16: Data for Korsmeyer Peppas model

\begin{tabular}{|c|c|}
\hline log time(hours) & $\log$ (\% cumulative drug release) \\
\hline 0 & 1.416307587 \\
\hline 0.301029996 & 1.498034724 \\
\hline 0.477121255 & 1.655522596 \\
\hline 0.602059991 & 1.699751032 \\
\hline 0.698970004 & 1.757471948 \\
\hline 0.77815125 & 1.79629674 \\
\hline 0.84509804 & 1.833529582 \\
\hline 0.903089987 & 1.855155577 \\
\hline 0.954242509 & 1.89795681 \\
\hline 1 & 1.913707914 \\
\hline 1.041392685 & 1.958420528 \\
\hline 1.079181246 & 1.998564458 \\
\hline
\end{tabular}




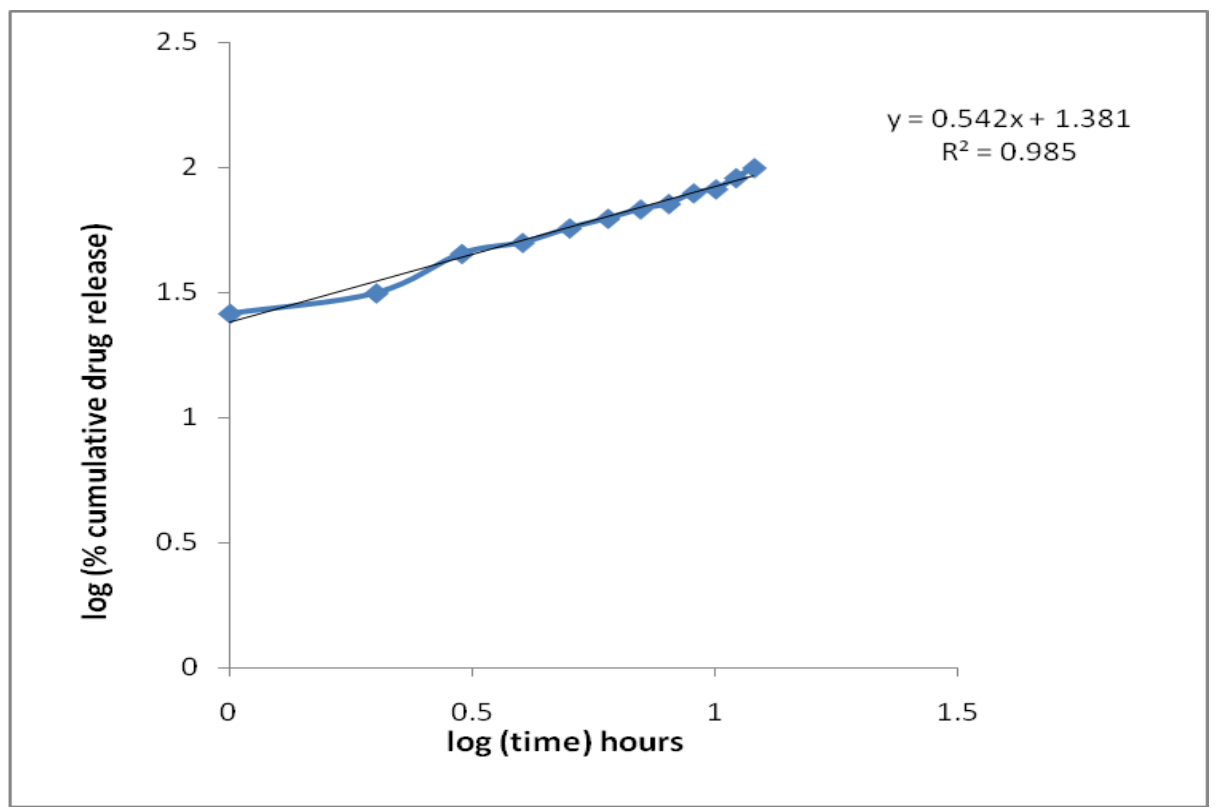

Figure No. 9: Korsmeyer Peppas plot for Dissolution of $\mathrm{F}_{4}$

Value of $\mathbf{R}^{2}$ for different models of $\mathbf{F}_{4}$ :

\begin{tabular}{|c|c|}
\hline Kinetic model & 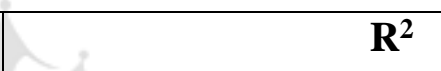 \\
\hline Zero-order & $\gamma / \gamma$ \\
\hline First-order & 0.924 \\
\hline Higuchi model & IAN \\
\hline Korsmeyer Peppas & 0.985 \\
\hline
\end{tabular}

Dissolution data of $\mathrm{F}_{4}$ were subjected to treatment with different kinetic models, on the basis of that drug release pattern was found to be best fitted with Higuchi equation.

\section{CONCLUSION}

A novel floating drug delivery system of Ranitidine $\mathrm{HCl}$ was formulated in an effort to increase the gastric retention time of the dosage form and to release the drug at controlled rate. Floating drug delivery system may be used for the possibility to replace the parenteral administration of drugs to oral pharmacotherapy that results in improved patient therapy.

The approach of present study was to develop the floating tablets of Ranitidine $\mathrm{HCl}$ using natural ulcer protective agent liquorice. These were found compatible with each other and tablets were successfully developed with better results. Five different batches were prepared using different ratio of polymers and little variation in effervescent agent sodium bicarbonate 
that result in significant difference in floating behaviour and release pattern of drug. On the basis of in-vitro release study and buoyancy, tablets from batch $\mathrm{F}_{4}$ were found to be best among all formulations.

\section{REFERENCES}

1.El-Kamel, A., et al., Preparation and evaluation of ketoprofen floating oral delivery system. International journal of pharmaceutics, 2001. 220(1-2): p. 13-21.

2. Tripathi, J., et al., Current state and future perspectives on gastroretentive drug delivery systems. Pharmaceutics, 2019. 11(4): p. 193.

3. Gupta, M.E., C. Amulya, and I.S. Babu, A REVIEW ON FLOATING DRUG DELIVERY SYSTEMS. 2019.

4. Arora, S., et al., Floating drug delivery systems: a review. Aaps PharmSciTech, 2005. 6(3): p. E372-E390.

5. Srikanth, P., S. Hemalatha, and S.V. Satyanarayana, Development and radiographical evaluation of floating tablets with combination of Amoxicillin Trihydrate and Ranitidine Hydrochloride. International Journal of Research in Pharmaceutical Sciences, 2019. 10(2): p. 1489-1499.

6. Arunachalam, A., et al., Floating drug delivery systems: A review. International Journal of Research in Pharmaceutical Sciences, 2011. 2(1): p. 76-83.

7. Malek Jafarian, M. and K. Ghazvini, In vitro susceptibility of Helicobacter pylori to licorice extract. Iranian Journal of Pharmaceutical Research, 2010: p. 69-72.

8. Aly, A.M., L. Al-Alousi, and H.A. Salem, Licorice: a possible anti-inflammatory and anti-ulcer drug. Aaps Pharmscitech, 2005. 6(1): p. E74-E82.

9. Ram, H.A., et al., Formulation and evaluation of floating tablets of liquorice extract. Pharmacognosy research, 2010. 2(5): p. 304.

10. Mastiholimath, V., et al., In vitro and in vivo evaluation of ranitidine hydrochloride ethyl cellulose floating microparticles. Journal of microencapsulation, 2008. 25(5): p. 307-314.

11. Dave, B.S., A.F. Amin, and M.M. Patel, Gastroretentive drug delivery system of ranitidine hydrochloride: formulation and in vitro evaluation. Aaps PharmSciTech, 2004. 5(2): p. 77-82.

12. Elmowafy, E.M., et al., Release mechanisms behind polysaccharides-based famotidine controlled release matrix tablets. AAPS PharmSciTech, 2008. 9(4): p. 1230-1239.

13. Wu, W., et al., Studies on nimodipine sustained-release tablet capable of floating on gastric fluid with prolonged gastric resident time. Yao xue xue bao= Acta Pharmaceutica Sinica, 1997. 32(10): p. 786-790.

14. Havaldar, V., et al., Floating matrix tablets of atenolol: Formulation and in vitro evaluation. Asian Journal of Pharmaceutics (AJP): Free full text articles from Asian J Pharm, 2014. 3(4).

15. Rahman, Z., M. Ali, and R. Khar, Design and evaluation of bilayer floating tablets of captopril. Acta Pharmaceutica, 2006. 56(1): p. 49-57.

16. Jaimini, M., A. Rana, and Y. Tanwar, Formulation and evaluation of famotidine floating tablets. Current drug delivery, 2007. 4(1): p. 51-55.

17. Kumar, R., et al., Formulation and evaluation of effervescent floating tablet of famotidine. Int $\mathrm{J}$ Pharmnt Res, 2009. 1(3): p. 754-763.

18. Rathore, J. and H.K. Parmar, Formulation and Evaluation of Floating Tablets of Norfloxacin. International Journal of Pharma Sciences and Research, 2015. 6(2): p. 23-27. 
www.ijppr.humanjournals.com

\begin{tabular}{|c|c|}
\hline & $\begin{array}{l}\text { Poonam Devi } \\
\text { Himalayan Institute Of Pharmacy } \\
\text { Kala-Amb, Distt -Sirmour, Himachal Pradesh(173030) }\end{array}$ \\
\hline & $\begin{array}{l}\text { Sunaina sharma } \\
\text { Himalayan Institute Of Pharmacy } \\
\text { Kala-Amb, Distt -Sirmour ,Himachal Pradesh(173030) }\end{array}$ \\
\hline & $\begin{array}{l}\text { Dr. Richa Ohri (Corresponding Author) } \\
\text { Lala Birkha Ram college of Pharmacy } \\
\text { Golpura, Distt Panchkula, Haryana (134109) }\end{array}$ \\
\hline
\end{tabular}

